\title{
EFFECTS OF COMPACTION DUE TO MACHINERY TRAFFIC ON SOIL PORE CONFIGURATION
}

\author{
Carlos Germán Soracco $^{(1)^{*}}$, Luis Alberto Lozano ${ }^{(2)}$, Rafael Villarreal(1), Telmo Cecilio \\ Palancar $^{(1)}$, Daniel Jorajuria Collazo(1), Guillermo Oliveiro Sarli(1) and Roberto Raúl \\ Filgueira $^{(2)}$
}

(1) Universidad Nacional de La Plata, Facultad de Ciencias Agrarias y Forestales, La Plata, Argentina.

(2) Consejo Nacional de Investigaciones Científicas y Técnicas, La Plata, Argentina.

* Corresponding author.

E-mail: gsoracco@agro.unlp.edu.ar

\begin{abstract}
Soil compaction has been recognized as a severe problem in mechanized agriculture and has an influence on many soil properties and processes. Yet, there are few studies on the long-term effects of soil compaction, and the development of soil compaction has been shown through a limited number of soil parameters. The objectives of this study were to evaluate the persistence of soil compaction effects (three traffic treatments: T0, without traffic; T3, three tractor passes; and T5, five tractor passes) on pore system configuration, through static and dynamic determinations; and to determine changes in soil pore orientation due to soil compaction through measurement of hydraulic conductivity of saturated soil in samples taken vertically and horizontally. Traffic led to persistent changes in all the dynamic indicators studied (saturated hydraulic conductivity, $\mathrm{K}_{\mathbf{0}}$; effective macro- and mesoporosity, $\varepsilon_{\mathrm{ma}}$ and $\varepsilon_{\mathrm{me}}$ ), with significantly lower values of $K_{0}, \varepsilon_{\mathrm{ma}}$, and $\varepsilon_{\mathrm{me}}$ in the T5 treatment. The static indicators of bulk density (BD), derived total porosity (TP), and total macroporosity $\left(\theta_{\mathrm{ma}}\right)$ did not vary significantly among the treatments. This means that machine traffic did not produce persistent changes on these variables after two years. However, the orientation of the soil pore system was modified by traffic. Even in T0, there were greater changes in $K_{0}$ measured in the samples taken vertically than horizontally, which was more related to the presence of vertical biopores, and to isotropy of $K_{0}$ in the treatments with machine traffic. Overall, the results showed that dynamic indicators are more sensitive to the effects of compaction and that, in the future, static indicators should not be used as compaction indicators without being complemented by dynamic indicators.
\end{abstract}


Keywords: effective porosity, total porosity, soil pore anisotropy, hydraulic conductivity.

\title{
RESUMO: EFEITO DA COMPACTAÇÃO DO SOLO PELO TRÁFEGO DE MÁQUINAS NA CONFIGURAÇÃO DOS POROS DO SOLO
}

\begin{abstract}
A compactação do solo tem sido reconhecida como um problema grave na agricultura mecanizada, influenciando em várias propriedades e processos do solo. Poucos são os relatos dos efeitos dessa compactação ao longo do tempo; a evolução da compactação do solo tem sido demonstrada por um número limitado de atributos do solo. Os objetivos deste trabalho foram avaliar a persistência dos efeitos da compactação do solo (três tratamentos com tráfego de máquina agrícola, sendo: T0, sem tráfego; T3, com três passadas de trator; e T5, cinco passadas de trator) na configuração do sistema poroso, utilizando determinações estáticas e dinâmicas; e determinar as mudanças na orientação do sistema poroso do solo após a compactação, utilizando os valores de condutividade hidráulica do solo saturado, em amostras coletadas na vertical e horizontal. O tráfego causou alterações em todos os indicadores dinâmicos estudados (condutividade hidráulica do solo saturado, $K_{0}$; e macro e mesoporosidade efetiva do solo, $\varepsilon_{m a}$ e $\varepsilon_{m e}$ ), com valores significativamente baixos de $K_{0}, \varepsilon_{m a}$ e $\varepsilon_{m e}$ no tratamento T5. Já os valores dos indicadores estáticos como a densidade do solo, a porosidade total derivada do solo e a macroporosidade total ( $\left.\theta_{\text {ma }}\right)$ não apresentaram variação significativa entre os tratamentos. Esse é um indicativo que o tráfego de máquinas não influenciou na alteração dessas variáveis após dois anos. Já na orientação do sistema poroso do solo, mesmo em T0, ocorreram maiores alterações em $K_{0}$ medidas nas amostras coletadas na vertical do que os valores medidos na horizontal, sendo mais relacionados à presença de bioporos na vertical e à isotropia de $K_{0}$ nos tratamentos onde houve tráfego de máquinas. Assim, os resultados evidenciaram que os indicadores dinâmicos são mais sensiveis aos efeitos da compactação e que, futuramente, os indicadores estáticos não serão utilizados como indicadores da compactação do solo, sem a necessidade do complemento de indicadores dinâmicos.
\end{abstract}

Palavras-chave: porosidade efetiva, porosidade total, anisotropia da porosidade do solo, condutividade hidráulica.

\section{INTRODUCTION}

In recent decades, in agricultural production organized to meet the demands of an increasing population, the weight of agricultural machines has steadily increased, leading to soil compaction processes (Berisso et al., 2012).

Soil compaction has been recognized as a severe problem in mechanized agriculture and has an influence on many soil properties and processes, as well as on crop yield (Servadio et al., 2005). Even with a lack of experimental data on the persistence of compaction effects, there is a generalized idea that negative effects of soil compaction persist long after the occurrence of traffic (Etana et al., 2013).

Soil compaction has traditionally been defined as a change in volume for a given dry mass of soil due to an applied load (Chamen et al., 2014). Bulk density (BD) is then used to evaluate the effects of traffic on soil quality (Petelkau, 1999; Arvidsson, 1999; Duttmann et al., 2014). This holds true only for a pure compaction process as variation of soil volume, but it does not include more complex processes like changes in pore orientation or tortuosity that result in no change in volume at all. Yet, these changes imply an intense deterioration of structure and homogenization of the pore system (Horn et al., 2003). These changes result in modification of soil hydraulic properties rather than modification of total porosity (TP). Results obtained by Tarawally et al. (2004) suggested that soil TP was not a good indicator of compaction effects, and that, therefore, it should not be used as a soil compaction index, as previously recommended by Al-Adawi and Reeder (1996), and later by Kuncoro et al. (2014a).

Characterization of the soil pore system is necessary to evaluate soil structure conditions because the size, shape, and continuity of pores affect many important soil processes; hence, their characterization allows quantification of soil structure quality. Evaluation and quantification of the soil pore system are widely applied tools for assessment of compaction in agricultural soils. Heavy machinery and intensive traffic can seriously compact soils, modifying soil structure and degrading its physical quality. In order to evaluate the impact of traffic on soil, it is necessary to quantify modifications to soil structure. Soil pore system configuration, i.e. pore size distribution, pore diameter, and continuity of macropores have a big impact on soil hydraulic properties (Hillel, 1998).

As the configuration of the soil pore system largely determines its hydraulic properties, any modification of this system will affect them. Therefore, changes in soil pore space are accompanied by modification of the hydraulic properties (Horton et al., 1994; Green 
et al., 2003). Soil compaction affects soil hydraulic properties and associated soil water flow. Flow in larger pores is more affected by compaction than flow in smaller pores. This observation suggests that compaction destroys mainly large pores, a phenomenon often measured in desorption curves (Abdollahi, 2014). Since infiltration rates measured under negative water potential are quite sensitive to compaction, the simplicity and quickness of these field techniques proves useful in quantifying compaction and other management effects on hydraulic properties (Horton et al., 1994). The tension disc infiltrometer is a valuable tool for understanding water movement through macropores and the soil matrix under near saturation conditions (Watson and Luxmoore, 1986; Logsdon and Jaynes, 1993; Moret and Arrúe, 2007). This device allows estimation of $\mathrm{K}$ from saturation to a few centimeters of suction head (Angulo-Jaramillo et al., 2000) and quantification of the role of macropores during infiltration (Bodhinayake et al., 2004; Soracco et al., 2012). This technique requires only minimal soil disturbance.

Another noted effect of soil compaction is a change in pore orientation (Dörner and Horn, 2006). This effect can be determined through the measurement of saturated $\mathrm{K}$ in samples taken vertically and horizontally (Soracco et al., 2010; Lozano et al., 2013).

In addition to minimal tillage, meadow rotations including alfalfa have been used and, when applied over several years (four or five), they may regenerate soil structure. Marsili et al. (1998) investigated the recovery of a clay soil cropped with alfalfa for five years, previously subjected to tracked tractors passes. They found no difference in BD between treatments with one and four passes of the tractor comparing to the control treatment. However, total macroporosity, expressed as the percentage of area occupied by pores larger than $50 \mu \mathrm{m}$ on a thin section, decreased in the surface layer (0.00-0.10 m) after a single pass, and such a decrease was more pronounced after four passes. The reduction in macroporosity following compaction from one and four tractor passes was due to the decrease in the proportion of elongated pores. Such pores are very important because many of these pores directly affect plant growth by promoting root penetration and storage and transmission of water and gases (Marsili et al., 1998).

Alakukku (1996a) studied two different soils (Cambic Vermisol and Mollic Gellisol) and found that top- and subsoil compaction of clay soil persisted for at least three years, despite annual plowing of the topsoil to $0.2 \mathrm{~m}$, cropping, deep freezing, and cracking due to drying.

Alakukku (1996b) emphasized that the longterm effects of soil compaction have seldom been documented, and that the persistence of subsoil compaction is often measured with a limited number of soil parameters, such as BD and penetrometer resistance. Berisso et al. (2012) found that even 14 years after a compaction event, the negative effects on soil porosity persisted. Moreover, these authors emphasize that there is a reason to believe that these compaction effects will persist for decades, or even longer (Berisso et al., 2012). They mentioned, however, that there are only limited experimental data on the persistence of the compaction effect on the functioning of soil pores.

The study of the effects of soil compaction and the changes it undergoes due to a forage crop, taking into account the connectivity and orientation of the porous system, would allow us to better understand the resulting changes in soil pore configuration, and the persistence of the compaction effect.

We hypothesized that static determinations such as TP and macroporosity derived from tension table measurements are not good indicators of soil compaction effects, and dynamic determinations such as $\mathrm{K}$ and effective macroporosity are well suited to establish these effects. We further hypothesized that the effects of soil compaction on soil pore configuration persist for a long time after traffic occurred.

The objectives of this study were to evaluate the persistence of soil compaction effects on pore system configuration, through static and dynamic determinations; and to determine changes in soil pore orientation due to soil compaction through the measurement of near-saturated hydraulic conductivity in samples taken vertically and horizontally.

\section{MATERIAL AND METHODS}

\section{Sites and treatments}

The experiment was carried out near the city of $\mathrm{La}$ Plata, Argentina, in the Research Field of the School of Agricultural and Forestry Sciences, Universidad Nacional de La Plata ( $\left.34^{\circ} 55^{\prime} \mathrm{S}, 57^{\circ} 57^{\prime} \mathrm{W}\right)$. The climate in the region is temperate, with temperature rarely dropping below $0{ }^{\circ} \mathrm{C}$ (so freezing of the soil does not occur) and annual rainfall of approximately $1,000 \mathrm{~mm}$. The soil was classified as a fine, silty, illitic, thermic Typic Argiudoll (USDA, 2006) with a silty loam A-horizon (clay content: $18 \%$, silt content: $61 \%)$. The organic matter content did not differ between treatments at the time of sampling (organic matter content: $34.4 \mathrm{~g} \mathrm{~kg}^{-1}$ ).

The traffic treatments were applied in June. Plots were managed under conventional tillage (CT) before the treatments (last tillage was performed two years before the treatments). The tractor used was a $78 \mathrm{~kW}$ (PTO), two-wheel drive (2WD), weighing $3.8 \mathrm{Mg}$ (1.2 and $2.6 \mathrm{Mg}$ on the front and rear axles, respectively) 
and new $7.50 \times 16$ and $18.4 \times 34(8$ ply) single tires. Inflation pressure was $95 \mathrm{kPa}$ in the front tires and $207 \mathrm{kPa}$ in the rear tires. This tractor model is commonly used on commercial farms in the region of the experiment. The tractor speed was $5.5 \mathrm{~km} \mathrm{~h}^{-1}$.

Three treatments were carried out on plots of $26 \mathrm{~m}$ length $\times 5 \mathrm{~m}$ width, where the experimental variable was traffic frequency of 0 , three, and five tractor passes in the same tracks (T0, T3, and T5, respectively). Plots were in completely randomized blocks with three replications.

An alfalfa (Medicago sativa L.) pasture was sown in May of the following year, which covered all the treatments. Soil sampling and field measurements were carried out two years after the treatments, in the subsequent June.

Dynamic determinations were made both in the field (tension disc infiltrometer determinations) and in the lab (saturated hydraulic conductivity, $\mathrm{K}$, on undisturbed samples). Static determinations were carried out in the lab (bulk density, BD; total porosity, TP; and total macroporosity on a tension table). Dynamic and static determinations are described below.

\section{Dynamic determinations}

\section{In-situ infiltration test}

A tension disc infiltrometer (Perroux and White, 1988) was used to determine the steady-state infiltration rate. The infiltration tests were carried out in June.

The infiltrometer disc had a base radius of 6.25 $\mathrm{cm}$. Infiltration measurements were conducted at four randomly-selected sites for each replication (three replications per treatment, 12 measurements per treatment, total number of measurements: 36 ). To consider only the effects of the treatments on soil water infiltration, the crop residues were removed from the soil surface. To ensure good hydraulic contact between the device and the soil, the soil surface was flattened with a spatula and a thin dry sand layer was spread on it. Infiltration runs were performed at three values of water pressure head $h$ (namely, -6, -3, and $0 \mathrm{~cm}$, applied in this order and at the same place). This sequence of supply water pressure heads was used because a descending order might cause hysteresis, with progressive drainage occurring close to the disk while wetting continues at the infiltration front (Jarvis and Messing, 1995). Flow monitoring continued until steady-state flow from the disc was reached. The cumulative infiltration was recorded every min up to $10 \mathrm{~min}$, every $5 \mathrm{~min}$ up to $30 \mathrm{~min}$, and every 10 min until the end of the test. When the amount of water that infiltrated did not change with time for four consecutive measurements taken at $10 \mathrm{~min}$ intervals, steady-state flow was assumed, and the corresponding steady-state infiltration rate was calculated based on the last four measurements. The time necessary to reach the steady state was around $1.5 \mathrm{~h}$ for each tension.

The soil hydraulic conductivity, $\mathrm{K}$, at the different soil water pressure heads, h (i.e., $\mathrm{K}_{6}, \mathrm{~K}_{3}$, and $\mathrm{K}_{0}$ ) were thus calculated from the cumulative water infiltration using the multiple-head method (Ankeny et al., 1991). Most of the decrease in water conductance is expected to occur at hydraulic pressure heads close to zero due to a reduction in different groups of macropores (Gebhardt et al., 2009). The procedure used to obtain $K$ was based on the analysis of steady-state flux from the tension disc infiltrometer and its dependence on the water pressure head. This dependence was described by Gardner's exponential model (Gardner, 1958).

\section{Water-conducting macro - and mesoporosity}

Water-conducting (or effective) macro- and mesoporosity ( $\varepsilon_{\mathrm{ma}}$ and $\varepsilon_{\mathrm{me}}$, respectively) were calculated using the Watson and Luxmoore (1986) procedure.

The classical capillary rise equation allows calculation of the maximum water-filled pore equivalent radius, $\mathrm{r}[\mathrm{L}]$, at a specific soil water pressure head, $\mathrm{h}[\mathrm{L}]$ :

$$
\mathrm{r}=2 \sigma \cos (\alpha) / \rho \mathrm{g}|\mathrm{h}| \quad \text { Eq. } 1
$$

where $\sigma$ is the surface tension of water $\left[\mathrm{M} \mathrm{T}^{-1}\right], \alpha$ is the contact angle between water and the pore wall (assumed to be zero), $\rho$ is the density of water $\left[\mathrm{M} \mathrm{L}^{-3}\right]$, and $g$ is the acceleration due to gravity $\left[\mathrm{L} \mathrm{T}^{-2}\right]$. We were aware of the fact that a might be other than $0^{\circ}$. Woche et al. (2005) analyzed the dependence between the contact angle and the soil texture and observed small contact angles of $0^{\circ}$ to $20^{\circ}$ for silty loam soils. Moreover, a strongly depends on water content and probably approached $0^{\circ}$ after a sufficient infiltration time (Buczko et al., 2006).

This procedure assumes that the equivalent pores with radii smaller than $\mathrm{r}$ calculated from equation 1 are filled with water and are responsible for the entire flux of water under a given water pressure head, and that the equivalent pores with radii larger than the value calculated from equation 1 are not contributing to the water flux. The hydraulically active (or water-conducting) porosity, conducting water in the pressure head interval corresponding to the two pore radii ra and $\mathrm{rb}(\mathrm{ra} \leq \mathrm{rb}), \varepsilon$ (ra,rb), (assuming pore radius equal to the minimum equivalent pore radius), is then given by (Watson and Luxmoore, 1986):

$$
\varepsilon(\mathrm{ra}, \mathrm{rb})=8 \mathrm{\eta} \Delta \mathrm{K}(\mathrm{ra}, \mathrm{rb}) / \rho \mathrm{g}(\mathrm{ra})^{2} \quad \text { Eq. } 2
$$

where $\Delta K(r a, r b)$ is the difference in $K$ values in the pressure head interval corresponding to ra and $\mathrm{rb}$, $\eta$ is the dynamic viscosity of water $\left[\mathrm{M} \mathrm{L}^{-1} \mathrm{~T}^{-1}\right], \rho$ is the density of water $\left[\mathrm{M} \mathrm{L}^{-3}\right]$, and $\mathrm{g}$ is the acceleration due to gravity $\left[\mathrm{L} \mathrm{T}^{-2}\right]$. Since ra is the minimum equivalent pore radius in the range, $\varepsilon(\mathrm{ra}, \mathrm{rb})$ is 
an estimation of the maximum water-conducting porosity. Implicitly assumed in equation 2 is a unit hydraulic gradient, i.e. steady-state conditions during infiltration (Wahl et al., 2004).

According to equation 1, infiltration at water pressure heads of -3 and $-6 \mathrm{~cm}$ will exclude pores with equivalent diameters $>1 \mathrm{~mm}$, and $>0.5 \mathrm{~mm}$, respectively. In our study we defined water-conducting macropores $\left(\varepsilon_{\text {ma }}\right)$ as those pores draining at $\mathrm{h}>-3 \mathrm{~cm}$ (equivalent $\mathrm{r}>0.5 \mathrm{~mm}$ ), and water-conducting mesopores $\left(\varepsilon_{\mathrm{me}}\right)$ as those draining at $\mathrm{h}$ between -3 and $-6 \mathrm{~cm}(0.5 \mathrm{~mm}>$ equivalent $\mathrm{r}>0.25 \mathrm{~mm})$.

\section{Pore orientation}

\section{Core sampling for laboratory determinations}

Samples were taken in June. In order to determine if the hydraulic properties of the soil horizons had direction-dependent behavior, undisturbed soil samples were collected in PVC cylinders $(15 \mathrm{~cm}$ height and $5.88 \mathrm{~cm}$ internal diameter), in vertical and horizontal directions (Petersen et al., 2008; Soracco, 2009). The inner surfaces of the cylinders were coated with a thin film of lithium grease to facilitate penetration into the soil and to prevent bypass flux of water between the cylinder wall and the soil core during the saturated hydraulic conductivity $\left(\mathrm{K}_{0}\right)$ measurements.

In each treatment, cylindrical cores at the surface $(0-15 \mathrm{~cm})$ were carefully collected in different orientations. For each replication and treatment, five cylinders were extracted, for a total of 45 samples. The location of the sampling sites was chosen at random. The sampling cylinders were not completely filled with soil, but only to around $60 \%$ of their volume, leaving the remaining part empty in order to be filled with several centimeters of water on top of the soil cores. The samples were covered with plastic caps to protect the soil from mechanical disturbances and evaporation.

\section{Laboratory Saturated Hydraulic Conductivity $\left(\mathrm{K}_{01}\right)$ determination}

Laboratory saturated hydraulic conductivity $\left(\mathrm{K}_{01}\right)$ was measured in samples taken vertically $\left(\mathrm{K}_{0 \mathrm{lv}}\right)$ and horizontally $\left(\mathrm{K}_{0 \mathrm{lh}}\right)$ using the constant head method (Klute and Dirksen, 1986). The undisturbed soil sample was positioned vertically. A constant water height was maintained on top of the sample, and the bottom end was open to the atmosphere.

The following relation was used to estimate $\mathrm{K}_{01}$ (Hillel, 1998):

$$
\frac{Q}{A}=\mathrm{q}=-\mathrm{K}_{01} \frac{\Delta \mathrm{H}}{\mathrm{D}}
$$

where $\mathrm{Q}$ is the volume of water flowing per unit of time $\left(\mathrm{L}^{3} \mathrm{~T}^{-1}\right)$, $\mathrm{A}$ is the cross-sectional area of the soil column $\left(\mathrm{L}^{2}\right)$, $\mathrm{q}$ is the flux $\left(\mathrm{L} \mathrm{T}^{-1}\right), \mathrm{K}_{01}$ is the saturated hydraulic conductivity $\left(\mathrm{L} \mathrm{T}^{-1}\right), \Delta \mathrm{H}$ is the hydraulic head drop across the soil column (L), D is the length of the column $(\mathrm{L})$, and $\Delta \mathrm{H} / \mathrm{D}$ is the hydraulic gradient (dimensionless).

The soil core with the sample was placed vertically inside a funnel with a barrier covered by a thin tissue to retain the soil in the core, at atmospheric pressure. On top of the cores, distilled water was siphoned from a common supply to the individual soil samples.

The $\mathrm{K}$ anisotropy factor (KA) was calculated for each treatment as $\mathrm{K}_{0 l v} / \mathrm{K}_{0 l h}$.

\section{Static measurements}

\section{Total porosity and total macroporosity}

Total porosity (TP) was estimated from BD. Bulk density (BD) was measured in each treatment using the core method (Blake and Hartge, 1986). Soil total macroporosity $\left(\theta_{\mathrm{ma}}(\%), \mathrm{r}>30 \mu \mathrm{m}\right)$ was calculated from the soil water retention at $-50 \mathrm{~cm}$ water pressure head. It was measured using a tension table with a hanging water column on undisturbed soil samples (sample size: $5 \mathrm{~cm}$ diameter; $5 \mathrm{~cm}$ height). Ten samples were taken in each replication, and three replications per treatment, for a total of 30 samples per treatment; the total number of samples was 90 .

\section{Statistical analysis}

In order to determine the effects of the factor, $\mathrm{K}_{0}$, $\mathrm{TP}, \theta_{\mathrm{ma}}, \varepsilon_{\mathrm{ma}}$, and $\varepsilon_{\mathrm{me}}$ were analyzed using ANOVA with traffic intensity and replication as factors (Sokal and Rohlf, 1995). $\mathrm{K}_{01}$ values were analyzed for each treatment separately using ANOVA with orientation and replication as factors. The least significant difference (LSD) multiple comparison test was used to compare the means of the different treatments or orientations. The Kolmogorov-Smirnov test was applied to determine if replicates of measured quantities within a treatment were normally or log-normally distributed. All statistical tests on $\mathrm{K}_{0}$ (and $\mathrm{K}_{01}$ ) were carried out using the log of the data since the statistical frequency distribution of the $\mathrm{K}_{0}$ (and $\mathrm{K}_{01}$ ) data was log-normal, which is usual for this soil property (Bagarello et al., 2006). The BD and pore size fractions were normally distributed and, thus, no transformations were performed on these variables. For all analyses, significance was determined at $\mathrm{p}=0.05$.

\section{RESULTS AND DISCUSSION}

\section{Traffic effects on dynamic indicators}

The values of hydraulic conductivity determined from water infiltration at different tensions, $\mathrm{K}_{0}$, $\mathrm{K}_{3}$, and $\mathrm{K}_{6}$; the derived water-conducting macro and mesoporosity $\left(\varepsilon_{\mathrm{ma}}\right.$ and $\varepsilon_{\mathrm{me}}$ ); the vertical and horizontal laboratory saturated hydraulic 
conductivity ( $\mathrm{K}_{0 l v}$ and $\mathrm{K}_{0 l \mathrm{~h}}$, respectively); and the respective anisotropy factor (KA) as a function of the traffic treatment are shown in table 1. The traffic significantly affected the dynamic indicators studied. $\mathrm{K}_{0}, \mathrm{~K}_{3}, \varepsilon_{\mathrm{ma}}$, and $\varepsilon_{\mathrm{me}}$ were significantly lower in the treatment with more traffic frequency (T5). This indicates that two years after the traffic, the negative effects remained in this treatment, affecting the flow through macro- and mesopores. This is in agreement with Alakukku (1996a), who found that traffic compaction produced reduced values of $\mathrm{K}_{0}$ in the wheel tracks, in comparison with areas without traffic, due to lower macroporosity values. Horton et al. (1994) concluded that soil compaction mainly affects water flux through macropores. Etana et al. (2013) found that macroporosity and saturated and near-saturated hydraulic conductivity were smaller in the compacted plots 14 years after the traffic occurred, although these differences were not statistically significant.

In contrast, Richard et al. (2001) found higher unsaturated Kin compacted soil than in uncompacted soil, while Zhang et al. (2006) found no significant differences between compacted and uncompacted soils. Our results show that, for the soil under study from the pampas region, soil compaction negatively affects water flux through meso- and macropores, and that this effect still persisted after two years.

Moreover, the values of $\mathrm{K}_{0}, \varepsilon_{\mathrm{ma}}$, and $\varepsilon_{\mathrm{me}}$ were similar to values previously reported in the region (Soracco et al., 2011, 2012; Lozano et al., 2014), and to values reported in other regions (Etana et al., 2013).

The orientation of the porosity, determined by $\mathrm{K}_{0}$ measurements, was significantly affected by both traffic frequencies. T3 and T5 presented isotropy of $\mathrm{K}_{01}$, whereas the treatment without traffic (T0) showed higher vertical $\mathrm{K}_{01}$. Moreover, the traffic treatments affected soil pore configuration, producing a change in pore orientation. The preferential vertical connectivity was modified and disappeared due to traffic. The traffic likely destroyed or blocked vertical biopores, which were abundant in the $\mathrm{T} 0$ treatment but scarce in the $\mathrm{T} 3$ and $\mathrm{T} 5$ treatments, as was observed at the time of field sampling and measurements.

This is in agreement with Dörner and Horn (2006), who concluded that changes in the geometry and continuity of the pore system exceed those of pore volume and lead to changes in the anisotropy of saturated hydraulic conductivity and air permeability. They emphasized that changes in soil structure due to soil compaction are of major importance.

\section{Traffic effects on static indicators}

The measured values of BD, derived TP, and total macroporosity $\left(\theta_{\mathrm{ma}}\right)$ did not vary significantly among treatments (Table 1). This means that the traffic did not produce persistent changes on these variables after two years.

The effects of traffic on BD and TP have been frequently documented in the bibliography. A significant increase in $\mathrm{BD}$ and a reduction in TP were found by Botta et al. (2009) after tractor passes on a fine clayey soil. The same trend was reported by Hassan et al. (2007). It is well-known that traffic processes leads to an increase in BD and its corresponding reduction in TP (Kuncoro et al., $2014 \mathrm{~b})$. The persistence of these traffic effects has been less reported, and there is a lack of information on this topic. Berisso et al. (2012), in the subsoil of a sandy clay loam soil, found persistent effects of traffic on soil pore configuration even 14 years after the compaction event. Our results are in disagreement with these reports. We found that effects of traffic on static indicators were not detectable two years after traffic, even for the most intense traffic event. This could be attributed to the fact that three and five tractor passes did not deliver a very extreme energy of compaction, and therefore its persistence is reduced as well. We choose this energy of compaction because it represents the common regional practice.

Overall, the results showed that dynamic indicators are more sensitive to compaction effects,

Table 1. Values of field hydraulic conductivity at 0,3 , and $6 \mathrm{~cm}$ water tension $\left(K_{0}, K_{3}\right.$, and $K_{6}$, respectively); water-conducting macro- and mesoporosity $\left(\varepsilon_{\mathrm{ma}}\right.$ and $\left.\varepsilon_{\mathrm{me}}\right)$; vertical and horizontal laboratory saturated hydraulic conductivity $\left(K_{0 l v}\right.$, and $K_{0 l h}$, respectively); saturated hydraulic conductivity anisotropy factor (KA); bulk density (BD); derived total porosity (TP), and total macroporosity $\left(\theta_{\text {ma }}\right)$ as a function of traffic treatments (traffic frequency of zero, three, and five tractor passes in the same tracks - T0, T3, and T5, respectively)

\begin{tabular}{|c|c|c|c|c|c|c|c|c|c|c|c|}
\hline Treatment & $\mathrm{K}_{0}^{(1)}$ & $\mathbf{K}_{3}$ & $\mathrm{~K}_{6}$ & $\varepsilon_{\mathrm{ma}}$ & $\varepsilon_{\mathrm{me}}$ & $\mathbf{K}_{01 \mathrm{v}}$ & $\mathbf{K}_{01 \mathrm{~h}}$ & KA & BD & TP & $\theta_{\mathrm{ma}}$ \\
\hline & \multicolumn{3}{|c|}{$\mathrm{cm} \mathrm{h}^{-1}$} & \multicolumn{2}{|c|}{$\mathrm{m}^{3} \mathrm{~m}^{-3} \times 100$} & \multicolumn{2}{|c|}{$\mathrm{cm} \mathrm{h}^{-1}$} & dimensionless & $\mathrm{kg} \mathrm{dm}^{-3}$ & \multicolumn{2}{|c|}{$\mathrm{m}^{3} \mathrm{~m}^{-3} \times 100$} \\
\hline T0 & $1.79 \mathrm{a}$ & $0.75 \mathrm{a}$ & $\overline{0.33} \mathrm{a}$ & $0.0009 \mathrm{a}$ & $\overline{0.0016} \mathrm{a}$ & 11.5 & $\overline{3.2}$ & $3.6^{(2)}$ & $1.17 \mathrm{a}$ & $55.8 \mathrm{a}$ & $\overline{19.7 \mathrm{a}}$ \\
\hline T3 & $1.59 \mathrm{a}$ & $0.73 \mathrm{a}$ & $0.39 \mathrm{a}$ & $0.0008 \mathrm{a}$ & $0.0012 \mathrm{a}$ & 4.5 & 5.7 & 0.8 & $1.20 \mathrm{a}$ & $54.7 \mathrm{a}$ & $18.5 \mathrm{a}$ \\
\hline $\mathrm{T} 5$ & $1.07 \mathrm{~b}$ & $0.45 \mathrm{~b}$ & $0.26 \mathrm{a}$ & $0.0005 \mathrm{~b}$ & $0.0007 \mathrm{~b}$ & 3.8 & 3.8 & 1.0 & $1.15 \mathrm{a}$ & $56.7 \mathrm{a}$ & $18.8 \mathrm{a}$ \\
\hline
\end{tabular}

Values followed by the same letter in each column are not significantly different (LSD test; $\mathrm{p}=0.05)$. ${ }^{(1)}$ Statistical analysis on $\mathrm{K}_{0}$, $\mathrm{K}_{3}$, and $\mathrm{K}_{6}$ was performed on log-transformed values. ${ }^{(2)}$ Values in bold mean significant differences between $\mathrm{K}_{0 \mathrm{lv}}$ and $\mathrm{K}_{0 \mathrm{lh}}$ for the respective treatment. 
and furthermore, that static indicators should not be used as compaction indicators without complementary dynamic indicators. Differences in the values of water-conducting porosity are significant; therefore, this kind of determination may detect property changes that would remain undetected if using BD, TP, or macroporosity. This is an important finding of this study.

\section{CONCLUSIONS}

Static determinations such as TP and macroporosity derived from tension table measurements are not good indicators of soil compaction effects; dynamic determinations such as $\mathrm{K}$ and effective macroporosity are better suited for detecting these effects.

Effects of soil compaction on soil pore configuration persist two years after the traffic occurred. The effects of this persistence are significantly shown through dynamic properties.

Soil compaction leads to a change in pore orientation that persists two years after the traffic event.

\section{ACKNOWLEDGMENTS}

The authors gratefully acknowledge the financial support of CONICET and UNLP and thank Leandro Aquino from the Federal University of Pelotas, Brazil, for translating the abstract to Portuguese.

\section{REFERENCES}

Abdollahi L, Schjønning P, Elmholt S, Munkholm LJ. The effects of organic matter application and intensive tillage and traffic on soil structure formation and stability. Soil Till Res. 2014;136:28-37.

Al-Adawi SS, Reeder RC. Compaction and subsoiling effects on corn and soybean yields and soil physical properties. Trans ASABE. 1996;39:1641-9.

Alakukku L. Persistence of soil compaction due to high axle load traffic. I. Short-term effects on the properties of clay and organic soils. Soil Till Res. 1996; 37:211-2.

Alakukku L. Persistence of soil compaction due to high axle load traffic. II. Long-term effects on the properties of fine-textured and organic soils. Soil Till Res. 1996b;37:223-38.

Angulo-Jaramillo R, Vandervaere JP, Roulier S, Thony JL, Gaudet JP, Vauclin M. Field measurement of soil hydraulic properties by disc and ring infiltrometers, a review and recent developments. Soil Till Res. 2000;55:1-29.

Ankeny MD, Ahmed M, Kaspar TC, Horton R. Simple field method for determining unsaturated hydraulic conductivity. Soil Sci Soc Am J. 1991;55:467-70.
Arvidsson J. Subsoil compaction research in Sweden - a review. In: van den Akker, JJH, Horn R, Arvidsson J, editors. Experiences with the impact and prevention of subsoil compaction in the European Community. Wageningen: Staring Center; 1999. p.44-49. (Report 168. DLO).

Bagarello V, Elrick DE, Iovino M, Sgroi A. A laboratory analysis of falling head infiltration procedures for estimating hydraulic conductivity of soils. Geoderma. 2006;135:322-34.

Berisso FE, Schjønning P, Keller T, Lamande M, Etana A, de Jonge LW, Iversen BV, Arvidsson J, Forkman J. Persistent effects of subsoil compaction on pore size distribution and gas transport in a loamy soil. Soil Till Res. 2012;122:42-51.

Blake GR, Hartge KH. Bulk density. In: Blake GR, editor. Methods of soil analysis, physical and minerological methods. $2^{\text {a }}$ ed. Madison: American Society of Agronomy; 1986. Pt 1. p.363-76. (Agronomy monograph, 8/9).

Bodhinayake W, Si BC, Xiao C. New method for determining water-conducting macro- and mesoporosity from tension infiltrometer. Soil Sci Soc Am J. 2004;68:760-9.

Botta GF, Tolon Becerra A, Bellora Tourn F. Effect of the number of tractor passes on soil rut depth and compaction in two tillage regimes. Soil Till Res. 2009;103:381-6.

Buczko U, Bens O, Hüttl RF. Tillage effects on hydraulic properties and macroporosity in silty and sandy soils. Soil Sci Soc Am J. 2006;70:1998-2007.

Chamen WCT, Moxey AP, Towers W, Balana B, Hallett PD. Mitigating arable soil compaction: A review and analysis of available cost and benefit data. Soil Till Res. 2014;146:10-25.

Dörner J, Horn R. Anisotropy of pore functions in structured Stagnic Luvisols in the Weichselian moraine region in $\mathrm{N}$. Germany. J Plant Nutr Soil Sci. 2006;169:213-20.

Duttmann R, Schwanebeck M, Nolde M, Horn R. Predicting soil compaction risks related to field traffic during silage maize harvest. Soil Sci Soc Am J. 2014;78:408-21.

Etana A, Larsbo M, Keller T, Arvidsson J, Schjønning P, Forkman J, Jarvis N. Persistent subsoil compaction and its effects on preferential flow patterns in a loamy till soil. Geoderma. 2013;192:430-6.

Gardner WR. Some steady-state solutions of the unsaturated moisture flow equation with application to evaporation from a water table. Soil Sci. 1958;85:228-31.

Gebhardt S, Fleige H, Horn R. Effect of compaction on pore functions in soils in a Saalean moraine landscape in North Germany. J Plant Nutr Soil Sci. 2009;172:688-95.

Green TR, Ahuja LR, Benjamin JG. Advances and challenges in predicting agricultural management effects on soil hydraulic properties. Geoderma. 2003;116:3-27.

Hassan FU, Ahmad M, Ahmad N, Kaleem Abbasi M. Effects of subsoil compaction on yield and yield attributes of wheat in the sub-humid region of Pakistan. Soil Till Res. 2007;96:361-6.

Hillel D. Environmental soil physics. New York: Academic Press; 1998.

Horn R, Way T, Rostek J. Effect of repeated tractor wheeling on stress/strain properties and consequences on physical properties in structured arable soils. Soil Till. Res. 2003;73:101-6.

Horton R, Ankeny MD, Allmaras RR. Effects of compaction on soil hydraulic properties. In: Soane BD, van Ouwerkerk C, editors. Soil compaction in crop production. London: Elsevier; 1994. p.141-65. 
Jarvis NJ, Messing I. Near-Saturated hydraulic conductivity in soils of contrasting texture measured by tension infiltrometers. Soil Sci Soc Am J. 1995;59:27-34.

Klute A, Dirksen C. Hydraulic conductivity and diffusivity: Laboratory methods. In: Klute A, editor Methods of soil analysis. Physical and mineralogical methods. Madison: American Society of Agronomy; 1986. Pt 1. p.687-734. (Agronomy monograph, 9).

Kuncoro PH, Koga K, Satta N, Muto Y. A study on the effect of compaction on transport properties of soil gas and water II: Soil pore structure indices. Soil Till Res. 2014a;143:180-7.

Kuncoro PH, Koga K, Satta N, Muto Y. A study on the effect of compaction on transport properties of soil gas and water I: Relative gas diffusivity, air permeability, and saturated hydraulic conductivity. Soil Till Res. 2014b;143:172-9.

Logsdon SD, Jaynes DB. Methodology for determining hydraulic conductivity with tension infiltrometers. Soil Sci Soc Am J. 1993;57:1426-31.

Lozano LA, Soracco CG, Buda VS, Sarli GO, Filgueira RR. Stabilization of soil hydraulic properties under a long term no-till system. R Bras Ci Solo. 2014;38:1281-92.

Lozano LA, Soracco CG, Cornelis W, Gabriels D, Sarli GO, Villarreal R. Anisotropy of pore size classes' connectivity related to soil structure under no tillage. Soil Sci. 2013;178:612-7.

Marsili A, Servadio P, Pagliai M, Vignozzi N. Changes of some physical properties of a clay soil following passage of rubber- and metal-tracked tractors. Soil Till Res. 1998;49:185-99.

Moret D, Arrúe JL. Dynamics of soil hydraulic properties during fallow as affected by tillage. Soil Till Res. 2007;96:103-13.

Perroux KM, White I. Designs for disc permeameters. Soil Sci Soc Am J. 1988;52:1205-15.

Petelkau H. Bodenbearbeitung und Bodenschadverdichtungen. In: KTBL H.266: Bodenbearbeitung und Bodenschutz. SchluBfolgerungen für gute Fachliche Praxis, 1999. p.56-79.

Petersen CT, Trautner A, Hansen S. Spatio-temporal variation of anisotropy of saturated hydraulic conductivity in a tilled sandy loam soil. Soil Till Res. 2008;100:108-13.

Richard G, Cousin I, Sillon JF, Bruand A, Guérif J. Effect of compaction on the porosity of a silty soil: Influence on unsaturated hydraulic properties. Eur J Soil Sci. 2001;52:49-58.
Servadio P, Marsili A, Vignozzi N, Pellegrini S, Pagliai M. Effects on some soil qualities in central Italy following the passage of four wheel drive tractor fitted with single and dual tires. Soil Till Res. 2005;84:87-100.

Sokal RR, Rohlf FJ. Biometry. New York: Freeman; 1995.

Soracco CG. Efecto de la compactación sobre el sistema poroso del suelo en diferentes situaciones de labranza: Modelización y realidad [tese]. La Plata: Universidad Nacional de La Plata; 2009.

Soracco CG, Lozano LA, Sarli GO, Gelati PR, Filgueira RR. Anisotropy of saturated hydraulic conductivity in a soil under conservation and no-till treatments. Soil Till Res. 2010;109:18-22.

Soracco CG, Lozano LA, Sarli GO, Gelati PR, Filgueira RR. Using tension disc infiltrometer to determine infiltration and water-conducting macroporosity and mesoporosity relationships in an agricultural silty loam soil. Soil Sci. 2011;176:459-63.

Soracco CG, Lozano LA, Balbuena R, Ressia JM, Filgueira RR. Contribution of macroporosity to water flux of a soil under different tillage systems. R Bras Ci Solo. 2012;36:1149-55.

Tarawally MA, Medina H, Frómeta ME, Itza CA. Field compaction at different soil-water status: effects on pore size distribution and soil water characteristics of a Rhodic Ferralsol in Western Cuba. Soil Till Res. 2004;76:95-103.

United States Department of Agriculture - USDA. Keys to soil taxonomy. $10^{\mathrm{a}}$ ed. Washington; 2006.

Wahl NA, Bens O, Buczko U, Hangen E, Hüttl RF. Effects of conventional and conservation tillage on soil hydraulic properties of a silty-loamy soil. Phys Chem Earth. 2004;29:821-9.

Watson K, Luxmoore R. Estimating macroporosity in a forest watershed by use of a tension infiltrometer. Soil Sci Soc Am J. 1986;50:578-82.

Woche SK, Goebel MO, Kirkham MB, Horton R, van der Ploegg RR, Bachmann J. Contact angle of soils as affected by depth, texture and land management. Eur J Soil Sci. 2005;56:239-51.

Zhang S, Grip H, Lövdahl L. Effect of soil compaction on hydraulic properties of two loess soils in China. Soil Till Res. 2006;90:117-25. 